\title{
MAXIMIZE THE UTILIZATION OF TRADITIONAL COOLING UNITS FOR BROILER HOUSES
}

\author{
N. S. M. Elkaoud ${ }^{(1)}$ and M. H. A. Hassan ${ }^{(2)}$
}

\begin{abstract}
This research was conducted in a poultry farm within the poultry fattening project in Sohag Governorate, Egypt. Latitude 26.556 and longitude 31.655, village of Al-Ahawi. This research aims to maximize the utilization of the current cooling system for the broiler poultry houses. The experiment was conducted in station No. 2 using 6 houses at a poultry age 35 days on 3 July 2018 where the mean ambient temperature was $30.5^{\circ} \mathrm{C}$ and the mean relative humidity was $47.4 \%$. The operating time of the cooling units under test was 8 hours, from 9:00 am to 5:00 pm. It should be noted that before 9:00 am all the houses were cool under the operating conditions of house4. The data showed that highest temperature increase was achieved at operating house 3 conditions (The cooling units are operated with nozzles arrangement (3) and air speed 2.5 $\mathrm{m} / \mathrm{s})$ with a value range of $19.3: 26.3{ }^{\circ} \mathrm{C}\left(\mathrm{Avg} .=24 .{ }^{\circ} \mathrm{C}\right)$ while the relative humidity ranged from 64.1 to $69.3 \%($ Avg. $=65.7 \%)$. It is not recommended that the fans run at operating points 3 (Air speed $2.5 \mathrm{~m} / \mathrm{s}$ ) under the same experimental conditions. It is recommended that reduce the number of nozzles inside cooling units from 12 to 8 or 10 nozzles leading to decrease relative humidity under the same experimental conditions. To reduce evaporation rate and rationalization of water consumption by $22 \mathrm{l} / \mathrm{hr}$, cooling units are used under operating conditions of houses 5 or 6 compared to house 4. Operating conditions for houses number 5 and 6 give total energy and cooling efficiency near normal operating conditions (house 4). But rationalization of water is a major reason to urge on change normal operating of the traditional cooling system and move forward to replace those traditional systems with the latest systems.
\end{abstract}

Keywords: traditional cooling units, evaporative cooling, broiler poultry housing.

(1) and (2): Lecturers of Agric. Eng., Fac. of Agric. Eng., Al-Azhar Univ., Assiut, Egypt. 


\section{INTRODUCTION}

$\mathrm{F}$ orasmuch, the traditional cooling units used in poultry broiler houses are consume large rates of water and electricity which leads to higher production costs and lower profit. There is no doubt that optimal operation of existing cooling system in poultry houses occurs only after a thorough study of the performance of the system. Chickens farmed for meat in particular are sensitive to high temperatures and humidity. High temperatures lower the chicken's metabolism and raise the mortality rate. which reduces production. High temperatures and humidity caused heat stress for poultry. 'Heat stress' is the inability of chickens to achieving a balance between body heat production and body heat loss to the surrounding environment. This can occur at all ages and in all types of poultry. Heat Stress not only causes suffering and death in the poultry, but also results in reduced or lost production that adversely affects the profit. So, a cooling system is critical in order to achieve high production rates and increase efficiency. Heat stress of poultry is one of the most challenging problems of poultry production causing substantial damages and affecting all parameters of production performance and is often associated with sudden and massive deaths. Main heat sources in housing facility include external temperature of the air released into the room, emission from heated roofs and walls and heat released by the birds themselves. When the temperature in poultry house exceeds $27^{\circ} \mathrm{C}$, the birds begin to feel uncomfortable and start panting. Ambient temperature in poultry house above $27{ }^{\circ} \mathrm{C}$ makes birds feel uncomfortable and they start panting, whereas temperatures above $30{ }^{\circ} \mathrm{C}$ make proper heat release highly difficult. (Ralebhat et al., 2016) summarized that high temperature in combination with high relative humidity in poultry shed leads to heat stress in poultry birds and in turn reduces their productivity and increases mortality significantly. The capital and operational cost of conventional evaporative air-cooling system is very high as compared to the investment standards of poultry management. Apart from this, poultry sheds are generally located in rural areas where schedule power cuts are normal affair. The operation cost of cooling system on generator power is 3-5 times higher. Hence, majority of the poultry operators do not use proper cooling system which makes them susceptible to the adverse 
effects of temperature on production cost and hence profits. So, it must be used of different techniques and management practices to eliminate effect of heat stress in poultry birds. Thus, reduces mortality, improve productivity and thereby increase profit for the farm owner. (Johann, 2015) reported that broiler chickens have an optimum growth rate when the in-house environmental conditions are maintained at a target temperature or in a range close to the target temperature, defined as the thermal comfort zone (TCZ). The TCZ is where chickens do not have to regulate their body temperature and can optimally convert feed to meat/ weight. Since chickens have no sweat glands, they use a panting technique to get rid of excess heat requiring more of their energy intake and thus reducing optimum growth rate. The target temperature typically changes during the growth cycle of the chickens and the TCZ widens as the chickens become older. Table 1 shows a typical guide for in-house temperature and humidity adapted from (Cobb, 2012) ranging from $34{ }^{\circ} \mathrm{C}$ on the first day to $18^{\circ} \mathrm{C}$ at harvest time.

Table (1): Temperature and humidity guide for broilers.

\begin{tabular}{|c|c|c|c|}
\hline $\begin{array}{c}\text { Age }- \\
\text { days }\end{array}$ & $\begin{array}{c}\text { Relative } \\
\text { Humidity } \\
(\%)\end{array}$ & $\begin{array}{c}\text { Temperature }^{\mathbf{O}} \mathbf{C}(\mathbf{F}) \text { for } \\
\text { chicks from 30 week old } \\
\text { parent flocks or younger }\end{array}$ & $\begin{array}{c}\text { Temperature }^{\mathbf{}} \mathbf{C}(\mathbf{F}) \text { for } \\
\text { chicks from 30 week old } \\
\text { parent flocks or older }\end{array}$ \\
\hline 0 & $30-50$ & $34(93)$ & $33(91)$ \\
\hline 7 & $40-60$ & $31(88)$ & $30(86)$ \\
\hline 14 & $40-60$ & $27(81)$ & $27(81)$ \\
\hline 21 & $40-60$ & $24(75)$ & $24(75)$ \\
\hline 28 & $50-70$ & $21(70)$ & $21(70)$ \\
\hline 35 & $50-70$ & $19(66)$ & $19(66)$ \\
\hline 42 & $50-70$ & $18(64)$ & $18(64)$ \\
\hline
\end{tabular}

(Cobb, 2012) presents a maximum air speed over the chicks based on their age as can be seen in Table 2. Still in order to improve the performance of the evaporative cooling units, extensive research has been conducted in analyzing the influences of such factors as moist air velocity, temperature and humidity, water velocity and temperature on the efficiency of various traditional and novel evaporative coolers (Lemouari et al., 2009). 
Table (2): Maximum wind speed across broiler chickens.

\begin{tabular}{|c|c|}
\hline Age of chickens (days) & Maximum wind speed $[\mathbf{m} / \mathbf{s}]$ \\
\hline $1-14$ & 0.3 \\
\hline $15-21$ & 0.5 \\
\hline $22-28$ & 0.875 \\
\hline $28+$ & $1.75-3.0$ \\
\hline
\end{tabular}

Since, air temperature and humidity are the two major parameters affecting thermal comfort significantly, and only sensible load can be handled by an evaporative cooling system, conventional evaporative cooling system is suitable for dry and temperate climate where the humidity is low (Heidarinejad et al., 2009). Evaporative cooling of broiler chickens during the hot summer months is essential to optimize bird growth and to minimize mortality. During extremely hot weather an entire house full of chickens can be lost if the cooling system is not operating properly. Cooling technology has improved over the years from high air speed ventilation to evaporative cooling. Evaporative cooling in broiler houses began as tunnel ventilation combined with fogging nozzles dispersed around the interior of the building. These systems could reduce the house air temperature by $6^{\circ}$ to $10^{\circ} \mathrm{F}$ below outside temperature, and provided a significant amount of heat stress relief. However, these systems tended to wet the litter too much. It was soon determined additional cooling was needed. The next system that broiler producers implemented included a two-inch cooling pad that was kept wet with a row of nozzles. The two-inch thick cooling pad was installed over the tunnel ventilation air inlet, and was able to drop the temperature of the incoming air by 7 to $15^{\circ} \mathrm{F}$. These systems greatly reduced excessive moisture in the building interior (wet litter) and improved the environment for the birds. The down side was that a large amount of water was needed to keep the cooling pads wet. Excess water was wasted by allowing it to run onto the ground around the building. The newest improvement in cooling technology is the six-inch pad with water recirculation. Six-inch pads have been designed to increase the evaporative cooling efficiency without a substantial increase in fan energy requirements. Six-inch pads permit more water to be evaporated into the ventilation air. Excess water is collected in a trough at the base of the pad 
and is pumped back to the top of the pad. Recirculation of pad runoff eliminates water wastage (John, 2006). Accordingly, this research aims to maximize the utilization of the current cooling system for poultry farm and study the effect of the number of sprayers used within the system and the speed of fans on the performance of traditional cooling units.

\section{MATERIAL AND METHODS}

This research was conducted in a poultry farm within the poultry fattening project in Sohag Governorate, Egypt. Latitude 26.556 and longitude 31.655 , village of Al-Ahawi. This evaluation was carried out during hot summer month July.

\section{Materials:}

\section{General description of the poultry farm:}

The poultry farm (Station No. 2) contained a total of eight houses. Each house measured $65 \mathrm{~m}$ length, $10 \mathrm{~m}$ width and $4 \mathrm{~m}$ height with a total housing capacity of 5,000 chickens. Angle of inclination of the roof is $30^{\circ}$. There was $12 \mathrm{~m}$ of space between each house and one silo is dedicated to store fodder for each house. The broiler poultry house as shown in Fig. (1).

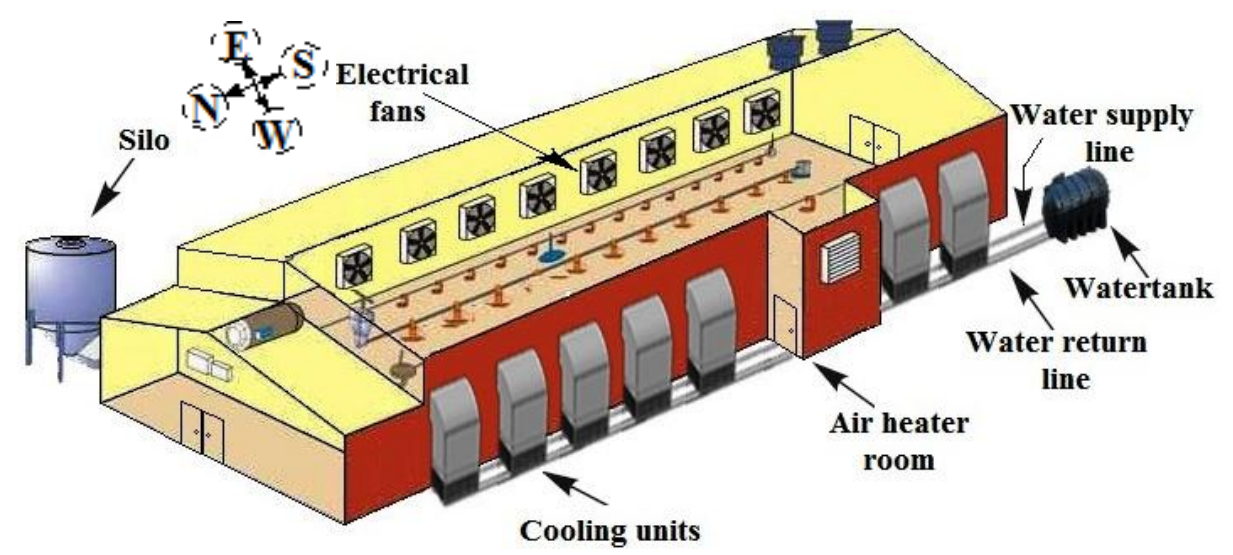

Fig. (1): An illustration of the broiler poultry house.

Eight $0.9 \mathrm{~m}$ diameter exhaust fans each with maximum capacity of 9000 $\mathrm{m}^{3} / \mathrm{h}$ (Axial ventilator FC050 Bauform Q (AS) Axial Fan Design FC050 Q (AS) FC_6_1) were located on one wall of the house. Electrical fan is shown in Fig. (2). 

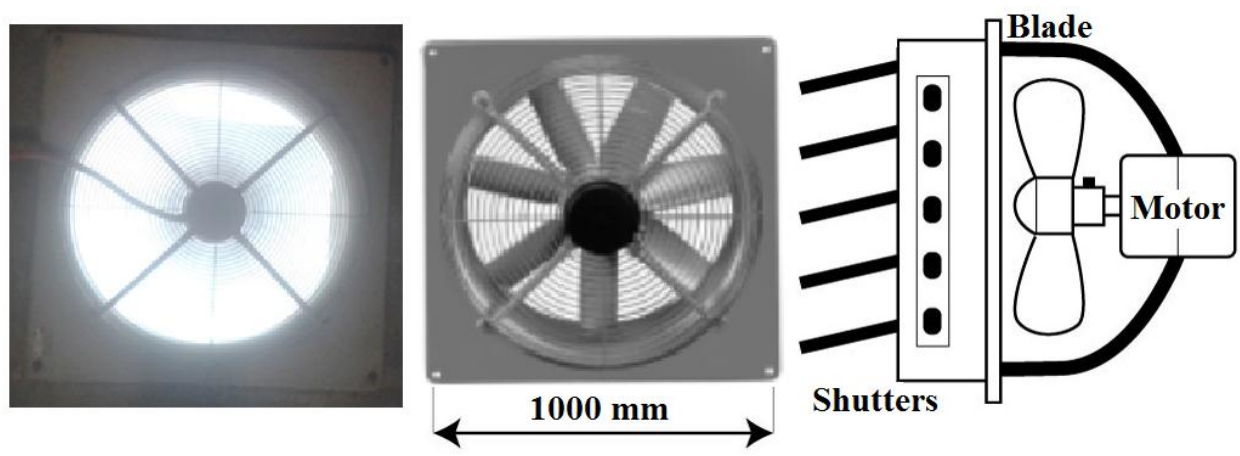

Fig. (2): Electrical fans.

The fans have four operating points are shown in Table (3). Seven units of cooling system were installed at the other wall of the building to provide relative uniformity of air distribution at the cross-sections of the house. Watertank is located at end of the house. It works as a water supply tank to the cooling unit sprinklers and as a reservoir for woter return line. There was air heater room includes diesel heater used to push hot air indoors during the winter.

Table (3): Operating points for electrical fans.

\begin{tabular}{|c|c|c|}
\hline Operating points & The volume flow, $\mathrm{m}^{3} / \mathrm{h}$ & Rated speed, $\mathrm{min}^{-1}$ \\
\hline 1 & 3200 & 1110 \\
\hline 2 & 5000 & 1210 \\
\hline 3 & 7000 & 1310 \\
\hline 4 & 9000 & 1410 \\
\hline
\end{tabular}

\section{Description of the current cooling system:}

The cooling system used for the poultry house of this farm is composed of traditional cooling units distributed on one side of the house and electric fans distributed on the opposite wall to provide relative uniformity of air distribution at the cross-sections of the house. Fig. (3) shows the traditional cooling unit. Dimensions of the cooling unit are $1.3 \mathrm{~m}$ width $\times$ $1.75 \mathrm{~m}$ height $\times 0.6 \mathrm{~m}$ thickness of the cavity. Dimensions of the window are $1.3 \mathrm{~m}$ width $\times 0.6 \mathrm{~m}$ length. The components of the cooling unit are: housing is made of galvanized metal sheets ( $3 \mathrm{~mm}$ thickness), sackcloth $\left(0.66 \mathrm{~m}^{2}\right)$, twelve spray nozzles (Lechler) the distance between them is 22 $\mathrm{cm}$. It distributed in two rows equally. Distance between the two rows is $22 \mathrm{~cm}$., water reservoir, floater, water supply pipe and water return line. 
Also, there are metal blades distributed over the sackcloth to reserve water drops and cool the air that passing through these metal blades. The metal blades are made of galvanized metal sheets (1 mm thickness). A pump (Pedrollo Italian water pump big impeller power: 1.5 HP. Head max: 38m. Flow max: 120 1/min. Inlet and outlet sizes: 1 inch) was used to move water from the sump to the water supply pipe.

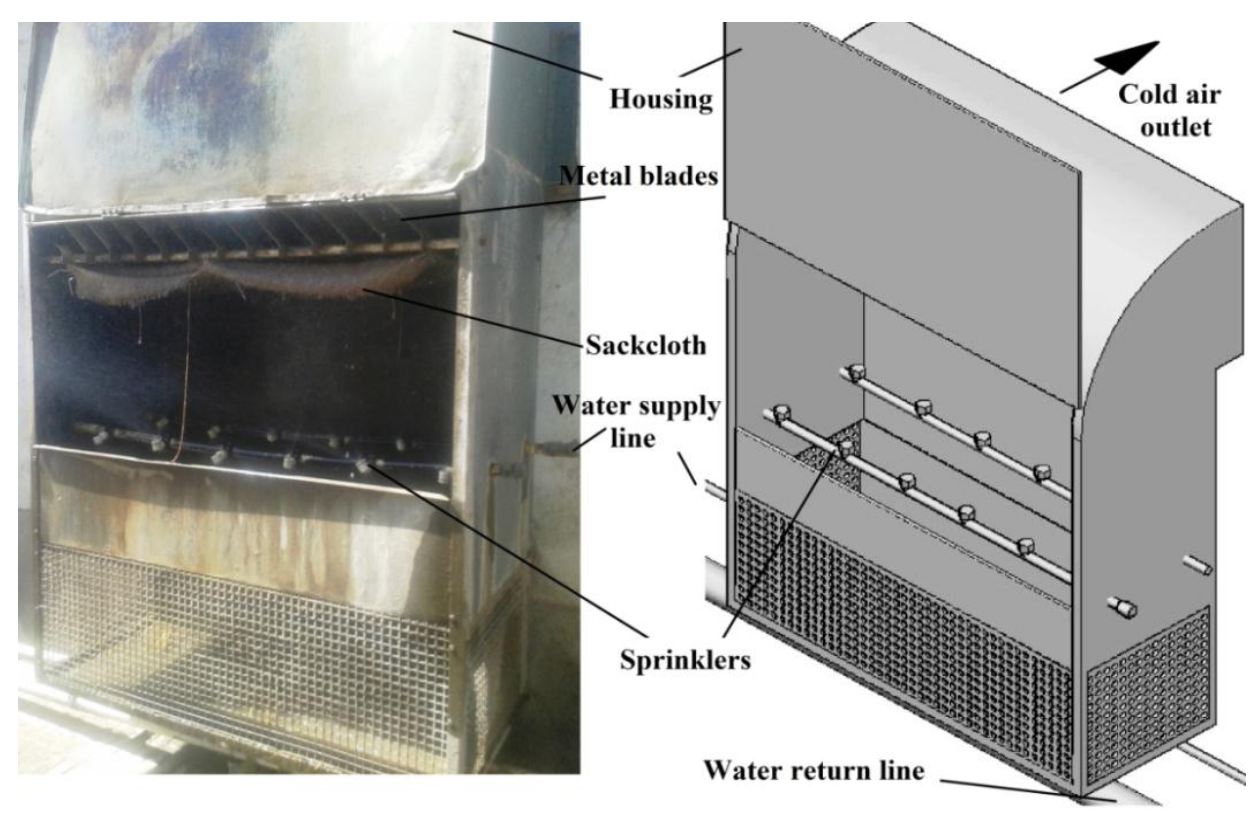

Fig. (3): Cooling unit.

\section{Spray nozzles:}

Table (4) shows general characteristics of the spray nozzle (Lechler) used to spray on the sackcloth. Lechler full cone nozzles have an extraordinarily uniform liquid distribution over a circular area on the sackcloth.

Table (4): Characteristics of spray nozzle.

\begin{tabular}{|c|c|c|c|c|}
\hline Type of sprinkler & $\begin{array}{c}\text { Flow rate } \\
(\text { liter/min })\end{array}$ & $\begin{array}{c}\text { Droplet size } \\
(\mu \mathrm{m})\end{array}$ & $\begin{array}{c}\text { Operating } \\
\text { pressure (bar) }\end{array}$ & $\begin{array}{c}\text { Spray } \\
\text { angle }\end{array}$ \\
\hline Lechler & 0.9 & 540 & 0.5 & $45^{\circ}$ \\
\hline
\end{tabular}

\section{Methods:}

This research was conducted in station No. 2 using 6 houses at a poultry age 35 days to study the experimental variables. Temperature and relative 
humidity data inside houses and outside (near each house) were recorded hourly. The number of measurement points was ten in house.

\section{Experiments variables:}

Tests of the cooling system was carried out under actual ranch conditions with considering the possible variables that may affect the temperature and humidity. Variables s of experiments are as following:

\section{(1) Nozzles arrangement:}

Fig. (4) shows full cone nozzles used in the cooling units where:

$\mathrm{D}=$ Spray diameter $=350 \mathrm{~mm}$.

$\mathrm{E}=$ Nozzle distance $=220,260$ and $325 \mathrm{~mm}$.

$\mathrm{N}=$ Number of nozzles 12,10 and 8 .

$\mathrm{O}=$ Overlap of spray angles $=\mathrm{D}-\mathrm{E}$

$\mathrm{H}=$ Installation distance of nozzles $=380 \mathrm{~mm}$.

$\alpha=$ Spray angle $=45^{\circ}$

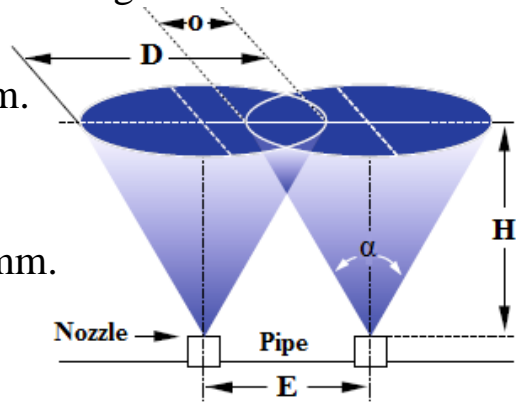

Fig. (4): Full cone nozzles.

The cooling system was tested under three nozzles arrangement shown in Fig. (5) and Table (5). Nozzles arrangement number (1) is currently used in the cooling unit.

Table (5): Details of nozzles arrangement.

\begin{tabular}{|l|c|c|c|}
\hline \multirow{2}{*}{\multicolumn{1}{|c|}{ Items }} & \multicolumn{3}{c|}{ Nozzles arrangement } \\
\cline { 2 - 4 } & N.A. (1) & N.A. (2) & N.A. (3) \\
\hline Number of nozzles (N) & 12 & 10 & 8 \\
\hline Nozzle distance (E, mm) & 220 & 260 & 325 \\
\hline Overlapping (O, mm) & 130 & 90 & 25 \\
\hline
\end{tabular}

\section{(2) Air speed inside:}

The cooling system was tested at a broiler age greater than 28 days, accordingly the experiments were done under two speed of air 2.5 and 3 $\mathrm{m} / \mathrm{s}$ at operating points of 3 and 4 for the fans respectively.

Consequently, the houses were cooled under test conditions as follows; Test 1 : House 1 Nozzles arrangement (1) + Air speed $2.5 \mathrm{~m} / \mathrm{s}$ Test 2 : House 2 Nozzles arrangement (2) + Air speed $2.5 \mathrm{~m} / \mathrm{s}$ Test 3 : House 3 Nozzles arrangement (3) + Air speed $2.5 \mathrm{~m} / \mathrm{s}$ Test 4 : House 4 Nozzles arrangement (1) + Air speed $3.0 \mathrm{~m} / \mathrm{s}$ Test 5 : House 5 Nozzles arrangement (2) + Air speed $3.0 \mathrm{~m} / \mathrm{s}$ 


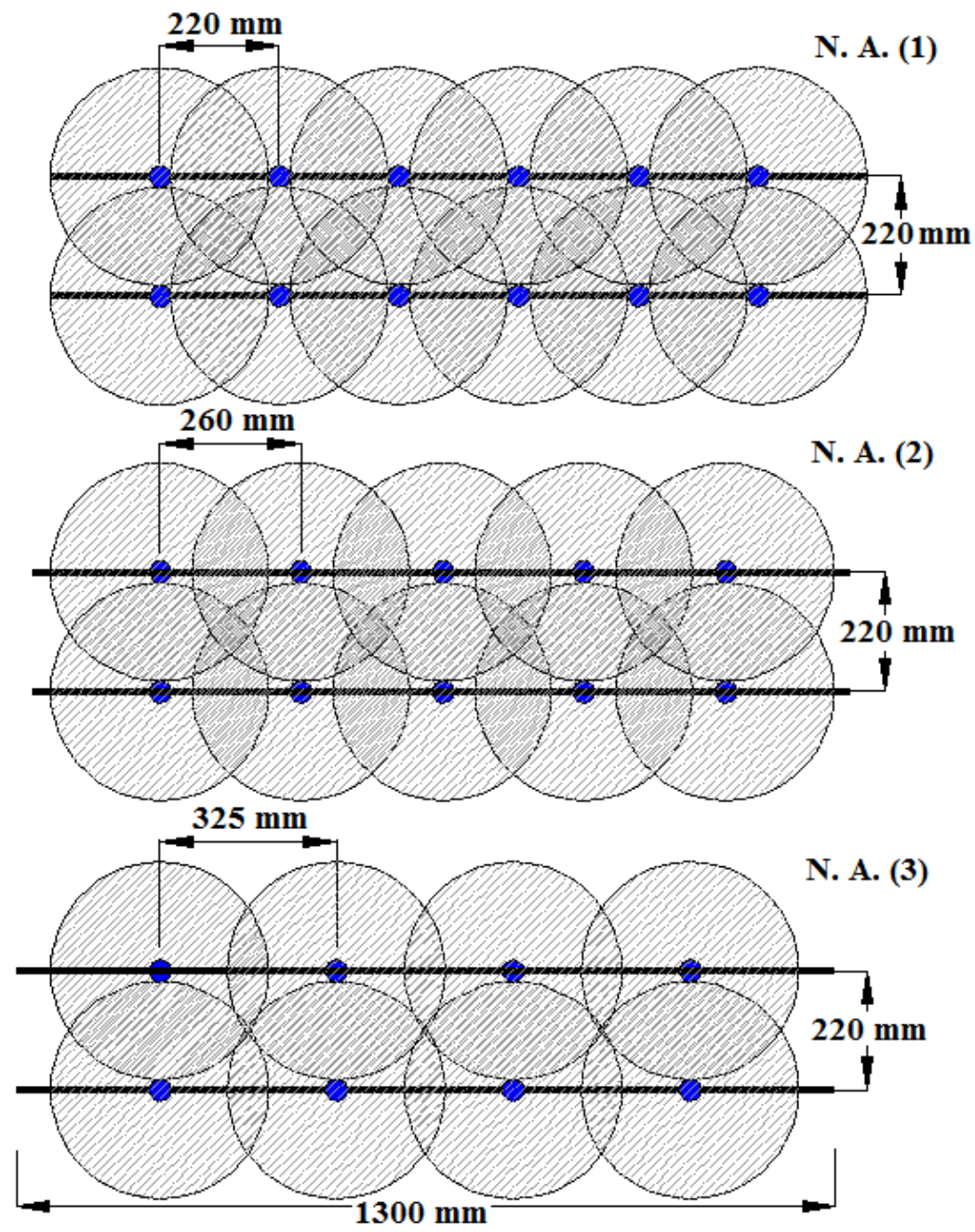

Test 6 : House 6 Nozzles arrangement (3) + Air speed $3.0 \mathrm{~m} / \mathrm{s}$

Fig. (5): Nozzles arrangement.

\section{Measurements:}

\section{(1) Temperature and humidity.}

The average value of temperature $\left({ }^{\circ} \mathrm{C}\right)$ and relative humidity $(\%)$ were recording during the experimental period at every hour inside and outside houses. Ambient temperature was measured by using mercurial thermometer (accuracy $1{ }^{\circ} \mathrm{C}$ ). The ambient relative humidity was measured using High Accuracy Thermo-Hygro device (accuracy 1\%).

\section{(2) Water loss rate.}

Water loss rate due to evaporative cooling is estimated by determining the amount of water added to the tank after one running hour. 


\section{(3) Air speed.}

The air speed was measured inside the house in front of the cooling unit window by the anemometer (Model AN100 and made in U.S.A). Its specifications are shown in Table (6).

Table (6): Specifications of the anemometer.

\begin{tabular}{|l|c|c|c|}
\hline \multirow{2}{*}{ Air speed, $\mathrm{m} / \mathrm{s}$} & Range & Resolution & Accuracy \\
\cline { 2 - 4 } & $0.40: 30.00$ & $0.01 \mathrm{~m} / \mathrm{s}$ & $\pm(3 \%+0.20)$ \\
\hline Air Flow, $\mathrm{m}^{3} / \mathrm{min}$ & $0: 9999$ & 1 & $\pm(1 \%+0.10)$ \\
\hline Air Temperature & $14-140^{\circ} \mathrm{F}\left(-10-60^{\circ} \mathrm{C}\right)$ & $0.1^{\circ} \mathrm{F} / \mathrm{c}$ & $4.0^{\circ} \mathrm{F}\left(2.0^{\circ} \mathrm{C}\right)$ \\
\hline
\end{tabular}

\section{(4) Cooling efficiency.}

Cooling efficiency $(\eta)$ was calculated by using the following equation according to, Ashrae (1983).

$$
\eta=\frac{T_{o}-T_{i}}{T_{o}-T_{w}}
$$

Where: $\mathrm{T}_{\mathrm{o}}$ and $\mathrm{T}_{i}$ : Outside and inside air temperature, $\left({ }^{\circ} \mathrm{C}\right)$.

$\mathrm{T}_{w}$ : wet temperature of the outside air, $\left({ }^{\circ} \mathrm{C}\right)$.

\section{(5) Total energy.}

Total energy was calculated by using the following equation:

Total energy, $(\mathrm{kW})=\frac{v}{v_{0}} \times \Delta h$

Where: $v$ : Volumetric air flow rate, $\left(1.944 \mathrm{~m}^{3} / \mathrm{s}\right.$ for houses 1,2 and 3 and $2.5 \mathrm{~m}^{3} / \mathrm{s}$ for houses 4,5 and 6 ).

$v_{\mathrm{o}}$ : specific air volume, $\mathrm{m}^{3} / \mathrm{kg}$ and $\Delta h$ : change in enthalpy, $\mathrm{kj} / \mathrm{kg}$.

\section{RESULTS AND DISCUSSION}

The experiment was conducted for broiler houses on 3 July 2018 where the mean ambient temperature was $30.5{ }^{\circ} \mathrm{C}$ and the mean relative humidity was $47.4 \%$. A total housing capacity of 5,000 chickens per house. The operating time of the cooling units under test was 8 hours, from 9:00 am to 5:00 pm. It should be noted that before 9:00 am all the houses were cool under the operating conditions of house 4 .

\section{(1) Temperature $\left(\mathrm{T},{ }^{\circ} \mathrm{C}\right)$ and relative humidity $(\mathrm{H}, \%)$.}

Average of inside temperature and relative humidity for each experimental houses at a broiler age 35 days and ambient air per operating hour are shown in Table (7). 
Table (7): The average of temperature and relative humidity inside and outside houses.

\begin{tabular}{|c|c|c|c|c|c|c|}
\hline \multicolumn{3}{c}{ Temperature, ${ }^{\circ} \mathrm{C}$} & \multicolumn{3}{c}{ Relative humidity, \% } \\
\multicolumn{1}{c}{ Max. } & Min. & Average & \multicolumn{2}{c|}{ Max. } & \multicolumn{1}{c|}{ Min. } & \multicolumn{1}{c|}{ Average } \\
\hline Outside & 34.6 & 24.5 & 30.5 & 53.9 & 43 & 47.4 \\
\hline House 1 & 23.7 & 18.8 & 20.8 & 69.5 & 67.2 & 67.9 \\
\hline House 2 & 24.9 & 19.0 & 22.5 & 69.7 & 66.0 & 66.8 \\
\hline House 3 & 26.3 & 19.3 & 24.7 & 69.3 & 64.1 & 65.7 \\
\hline House 4 & 19.8 & 18.5 & 18.9 & 69.8 & 68 & 68.9 \\
\hline House 5 & 20.2 & 18.6 & 19.3 & 69.1 & 61.8 & 64.1 \\
\hline House 6 & 20.5 & 18.9 & 19.9 & 69.7 & 57.1 & 61.5 \\
\hline
\end{tabular}

The temperature of ambient air ranged from 24.5 to $34.6{ }^{\circ} \mathrm{C}($ Avg. $=30.5$ ${ }^{\circ} \mathrm{C}$ ) while humidity ranged from 43 to $53.9 \%($ Avg. $=47.4 \%)$ during the hours of the experiment. The average of air temperature at inside houses were $20.8,22.5,24.7,18.9,19.3$ and $19.9^{\circ} \mathrm{C}$ for house 1 , house 2 , house 3 , house 4 , house 5 and house 6 , respectively.

While the average of relative humidity at inside houses were 67.9, 66.8, $65.7,68.9,64.1$ and $60.8 \%$ for house 1 , house 2 , house 3 , house 4 , house 5 and house 6 , respectively. From these results, and in general lowest temperature reduction was achieved at inside all houses compared to the temperature of ambient air while the relative humidity increased at different rates for all houses as a result of the evaporative cooling. It is clear that the lowest average temperatures were in houses 4,5 and 6 but there is considerable variation between those houses in the relative humidity. Also, the data in Table (7) shows that the highest temperature increase was achieved at operating house 3 conditions (The cooling units are operated with nozzles arrangement (3) and air speed $2.5 \mathrm{~m} / \mathrm{s}$ ) with a value range of $19.3: 26.3{ }^{\circ} \mathrm{C}\left(\mathrm{Avg} .=24.7^{\circ} \mathrm{C}\right)$ while the relative humidity ranged from 64.1 to $69.3 \%$ (Avg. $=65.7 \%$ ). The results also showed that the lowest temperature reduction was achieved at operating house 4 conditions (The cooling units are operated with nozzles arrangement (1) and air speed $3.0 \mathrm{~m} / \mathrm{s})$ with a value range of $18.5: 19.8{ }^{\circ} \mathrm{C}($ Avg. $=18.9$ ${ }^{\circ} \mathrm{C}$ ). Thus, air temperature was reduced from 30.5 to $18.9{ }^{\circ} \mathrm{C}$, while the relative humidity increased from $47.4 \%$ to $68.9 \%$. Fig. (6) shows air temperature and relative humidity of tested houses under different 
operating conditions of cooling units during the time of the experiment. Fig. (6) indicates that in the beginning of the experiment at 9 am air temperatures and relative humidity inside all the houses were very similar where they range from 18.5 to $19.3{ }^{\circ} \mathrm{C}$ and 69.1 to $69.8 \%$ respectively. This is due to that all the houses were cooled under the same operating conditions for cooling units.

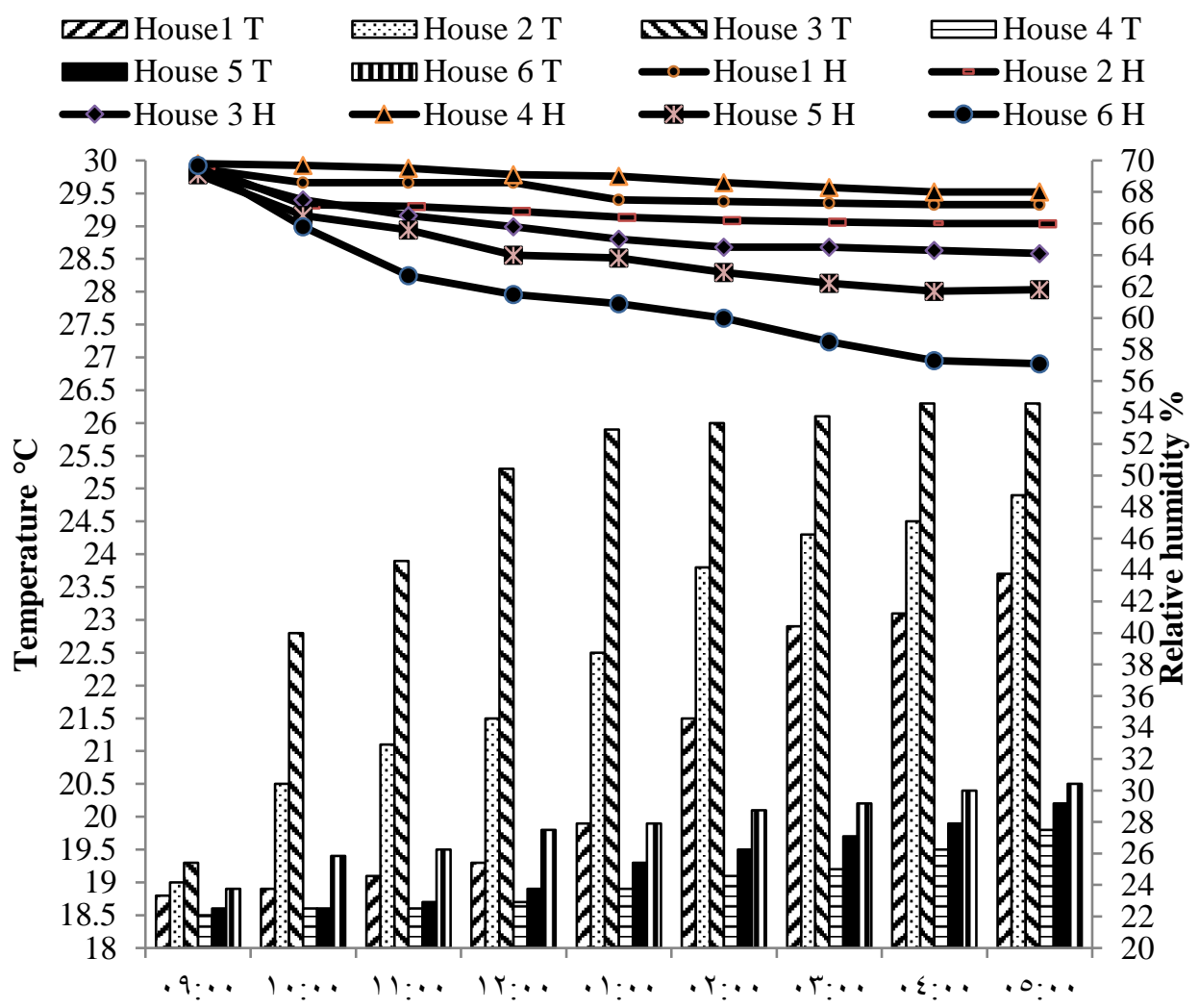

Local time

Fig. (6): Air temperature and relative humidity of inside houses as affected by local time during experiments.

Under operating conditions houses 1, 2, 3, 4,5 and 6 the air temperature increased from 18.8 to 23.7 , from 19.0 to 24.9 , from 19.3 to 26.3 , from 18.5 to 19.8 , from 18.6 to 20.2 and 18.9 to $20.5{ }^{\circ} \mathrm{C}$ while relative humidity decreased from 69.5 to $67.2,69.7$ to $66.0,69.3$ to $64.1,69.8$ to $68.0,69.1$ to 61.8 and 69.7 to $57.1 \%$ respectively. It is clear that in case of houses 1, 2 and 3 whenever operating hours increased the air temperature increased significantly where average increase temperature 
rate at operating hours was $25 \%\left(6{ }^{\circ} \mathrm{C}\right)$ while there was a slight decrease in relative humidity. This is may be due to reduce of the speed for suction fans which led to reduce ventilation rate and increased air temperatures regardless of the number of nozzles inside cooling units. It is particularly problematic when high temperatures are associated with high air humidity. Hence, makes poultry feel uncomfortable and they start panting. Accordingly, it is not recommended that the fans run at operating points 3 (Air speed $2.5 \mathrm{~m} / \mathrm{s}$ ) under the same experimental conditions at a poultry age 35 days. Also, it is clear that in case of the of house 4 (Normal operating conditions) air temperature was increased from 18.5 to $19.8{ }^{\circ} \mathrm{C}$, while the relative humidity reduced from $69.8 \%$ to $68.0 \%$ during the test hours. This slight difference in temperature $\left(1.3{ }^{\circ} \mathrm{C}\right)$ and relative humidity $(1.8 \%)$ is reasonable and consistent with high ambient air temperature during the daytime. But it is noticeable that high relative humidity inside the house makes poultry feel uncomfortable and breathing difficulty. In case of the houses 5 and 6 , air temperatures were increased from 18.6 to $20.2{ }^{\circ} \mathrm{C}$ and from 18.9 to $20.5{ }^{\circ} \mathrm{C}$ while the relative humidity reduced from 69.1 to $61.8 \%$ and from 69.7 to $57.1 \%$ respectively. It is clear that under operating conditions of houses 5 and 6 there was a slight increase in air temperature inside the houses it may be due to high temperatures outside but it is remarkable that relative humidity decreased significantly where average decrease humidity rate at operating hours was $18 \%$. This is may be due to reduce of the number of nozzles inside cooling units. Accordingly, it is recommended that reduce the number of nozzles inside cooling units from 12 to 8 or 10 nozzles leading to decrease relative humidity under the same experimental conditions at a poultry age 35 days.

\section{(2) Water loss rate.}

Fig. (7) shows water consumption during evaporative cooling ( $1 / \mathrm{h})$ under different operating conditions for each experimental house. The water consumption to reduced of tempereature from 30.5 to 20.8 , from 30.5 to 22.5, from 30.5 to 24.7 , from 30.5 to 18.9 , from 30.5 to 19.3 and from 30.5 to $19.9{ }^{\circ} \mathrm{C}$ at $47.4 \%$ relative humidity were $34.5,32.8,30.5,66.8$, 52.5 and $44.8 \mathrm{l} / \mathrm{h}$ for houses $1,2,3,4,5$ and 6 (7.5, 7.1, 6.6, 14.5, 11.4 and $9.7 \mathrm{l} / \mathrm{h}$ per $\mathrm{m}^{2}$ of sackcloth used), respectively. 


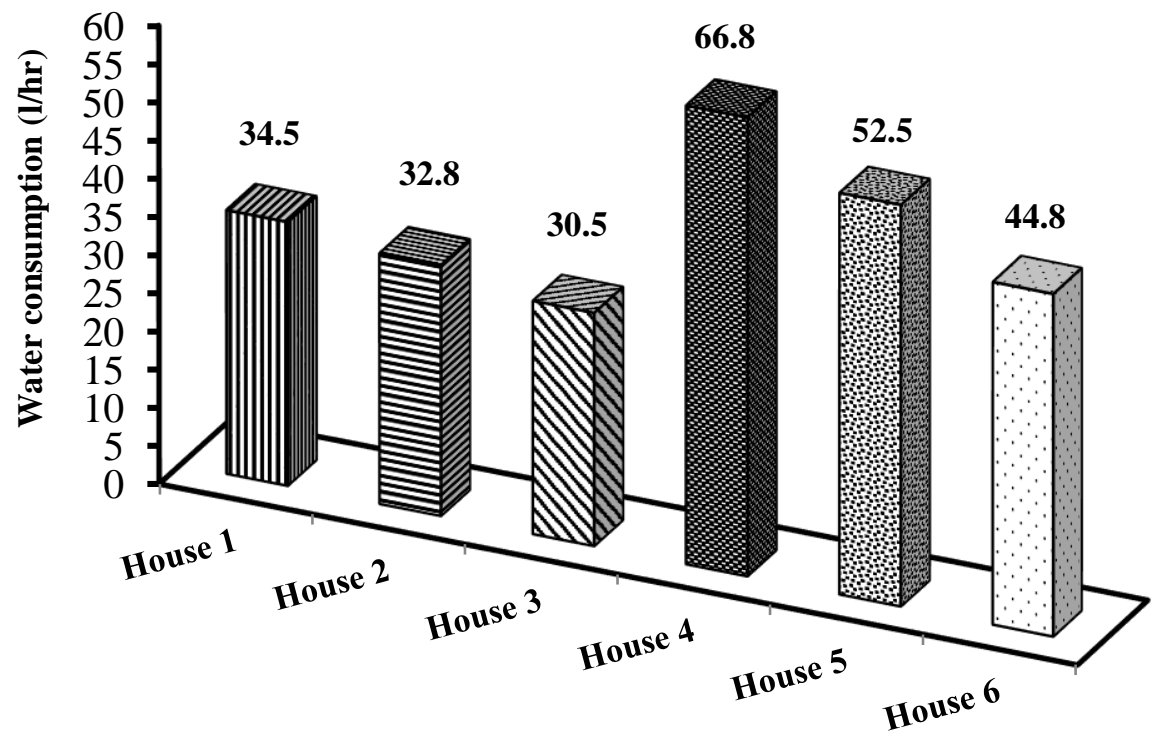

Fig. (7): Water consumption rate during evaporative cooling $(1 / \mathrm{h})$ for each experimental houses.

Fig. (7) indicates that the highest amount of water consumption was 66.8 $1 / \mathrm{hr}$ under operating conditions of house 4 (At air speed of $3.0 \mathrm{~m} / \mathrm{s}$ ), while the lowest amount was $30.5 \mathrm{l} / \mathrm{hr}$ under operating conditions of house 3 (At air speed of $2.5 \mathrm{~m} / \mathrm{s}$ ). It is clear that cooling water consumption was increased by increasing air speed. Also, cooling water consumption was found to be influenced by the number of nozzles inside cooling units. Accordingly, to reduce evaporation rate and rationalization of water consumption by $22 \mathrm{l} / \mathrm{hr}$, cooling units are used under operating conditions of houses 5 or 6 compared to house 4 .

\section{(3) Cooling units performance.}

Wet bulb temperature (WT), specific air volume and enthalpy outside and inside houses were found from the psychometric chart using average dry bulb temperature and relative humidity. The average of dry bulb temperature (DT), relative humidity (RH), wet bulb temperature (WT), specific air volume and enthalpy of ambient air (Air entering the cooling units) were $30.5{ }^{\circ} \mathrm{C}$ and $47.4 \%, 21.9{ }^{\circ} \mathrm{C}, 0.87 \mathrm{~m}^{3} / \mathrm{kg}$ and $64 \mathrm{Kj} / \mathrm{Kg}$ respectively as showen in Table (8). It indicates that total energy and cooling efficiency $(\eta)$ for tested houses. It is clear that total energy and cooling efficiency of houses 1, 2 and 3 (At volumetric air flow rate of 
$7000 \mathrm{~m}^{3} / \mathrm{hr}$ ) were less than houses 4, 5 and 6 (At volumetric air flow rate of $9000 \mathrm{~m}^{3} / \mathrm{hr}$ ). Also, it is clear that in case of the of house 4 (Normal operating conditions), total energy to reduced of the air temperature from 30.5 to $18.9^{\circ} \mathrm{C}$ and increased of the relative humidity from 47.4 to $68.9 \%$ was $63.5 \mathrm{~kW}$ with $76.4 \%$ cooling efficiency. In case of the houses 5 and 6, total energy to reduced of the air temperature from 30.5 to 19.3 and from 30.5 to $19.9{ }^{\circ} \mathrm{C}$ and increased of the relative humidity from 47.4 to 64.1 and from 47.4 to $61.5 \%$ were 65.5 and $63.9 \mathrm{~kW}$ with 72.7 and 69.7 $\%$ cooling efficiency, respectively. Accordingly, operating conditions for houses number 5 and 6 give total energy and cooling efficiency near normal operating conditions (house 4). But rationalization of water is a major reason to urge on change normal operating of the traditional cooling system.

Table (8): Average of (DT) and (WT), (RH), specific air volume, enthalpy, total energy and cooling efficiency $(\eta)$ for tested houses.

\begin{tabular}{lccccccc}
\hline & $\begin{array}{c}\mathrm{DT}, \\
{ }^{\circ} \mathrm{C}\end{array}$ & $\begin{array}{c}\mathrm{WT}, \\
{ }^{\circ} \mathrm{C}\end{array}$ & $\begin{array}{c}\mathrm{RH}, \\
\%\end{array}$ & $\begin{array}{c}\text { Specific } \\
\text { volume, } \\
\mathrm{m}^{3} / \mathrm{kg}\end{array}$ & $\begin{array}{c}\text { Enthalpy, } \\
\mathrm{Kj} / \mathrm{Kg}\end{array}$ & $\begin{array}{c}\text { Total } \\
\text { energy, } \\
(\mathrm{kW})\end{array}$ & $\begin{array}{c}\eta \\
\%\end{array}$ \\
\hline Outside & 30.5 & 21.9 & 47.4 & 0.87 & 64 & - & - \\
\hline House 1 & 20.8 & 16.8 & 67.9 & 0.833 & 47.45 & 38.6 & 70.8 \\
\hline House 2 & 22.5 & 18.3 & 66.8 & 0.84 & 51.6 & 28.7 & 65.5 \\
\hline House 3 & 24.7 & 20.1 & 65.7 & 0.85 & 57.59 & 14.7 & 55.8 \\
\hline House 4 & 18.9 & 15.3 & 68.9 & 0.832 & 42.868 & 63.5 & 76.4 \\
\hline House 5 & 19.3 & 15.1 & 64.1 & 0.833 & 42.158 & 65.5 & 72.7 \\
\hline House 6 & 19.9 & 15.3 & 61.5 & 0.834 & 42.676 & 63.9 & 69.7 \\
\hline
\end{tabular}

\section{CONCLUSION}

Overall results of this research may be concluded as follow:

1- The average of dry bulb temperature, relative humidity, wet bulb temperature, specific air volume and enthalpy of ambient air were $30.5^{\circ} \mathrm{C}$ and $47.4 \%, 21.9^{\circ} \mathrm{C}, 0.87 \mathrm{~m}^{3} / \mathrm{kg}$ and $64 \mathrm{Kj} / \mathrm{Kg}$ respectively.

2- The temperature of ambient air ranged from 24.5 to $34.6{ }^{\circ} \mathrm{C}$ (Avg. $=$ $30.5^{\circ} \mathrm{C}$ ) while humidity ranged from 43 to $53.9 \%($ Avg. $=47.4 \%)$ during the hours of the experiment. 
3- The average of air temperature at inside houses were 20.8, 22.5, 24.7, 18.9, 19.3 and $19.9^{\circ} \mathrm{C}$ under operating conditions house 1 , house 2 , house 3 , house 4 , house 5 and house 6 , respectively.

4- The average of relative humidity at inside houses were $67.9,66.8$, $65.7,68.9,64.1$ and $60.8 \%$ for house 1 , house 2 , house 3 , house 4 , house 5 and house 6 , respectively.

5- In case of houses 1, 2 and 3 whenever operating hours increased the air temperature increased significantly where average increase temperature rate at operating hours was $25 \%\left(6{ }^{\circ} \mathrm{C}\right)$ while there was a slight decrease in relative humidity.

6- In case of the of house 4 (Normal operating conditions) air temperature was increased from 18.5 to $19.8{ }^{\circ} \mathrm{C}$, while the relative humidity reduced from $69.8 \%$ to $68.0 \%$ during the test hours.

7- In case of the houses 5 and 6, air temperatures were increased from 18.6 to $20.2{ }^{\circ} \mathrm{C}$ and from 18.9 to $20.5^{\circ} \mathrm{C}$ while the relative humidity reduced from 69.1 to $61.8 \%$ and from 69.7 to $57.1 \%$ respectively.

8- The water consumption to reduced of tempereature from 30.5 to 20.8, from 30.5 to 22.5 , from 30.5 to 24.7 , from 30.5 to 18.9 , from 30.5 to 19.3 and from 30.5 to $19.9{ }^{\circ} \mathrm{C}$ at $47.4 \%$ relative humidity were 34.5 , $32.8,30.5,66.8,52.5$ and $44.8 \mathrm{l} / \mathrm{h}$ for houses $1,2,3,4,5$ and $6(7.5$, $7.1,6.6,14.5,11.4$ and $9.7 \mathrm{l} / \mathrm{h}$ per $\mathrm{m}^{2}$ of sackcloth used), respectively.

9- Total energy and cooling efficiency of houses 1, 2 and 3 (At volumetric air flow rate of $7000 \mathrm{~m}^{3} / \mathrm{hr}$ ) were less than houses 4,5 and 6 (At volumetric air flow rate of $9000 \mathrm{~m}^{3} / \mathrm{hr}$ ).

10- In case of the of house 4, total energy to reduced of the air temperature from 30.5 to $18.9{ }^{\circ} \mathrm{C}$ and increased of the relative humidity from 47.4 to $68.9 \%$ was $63.5 \mathrm{~kW}$ with $76.4 \%$ cooling efficiency. While in case of the houses 5 and 6 , total energy to reduced of the air temperature from 30.5 to 19.3 and from 30.5 to $19.9{ }^{\circ} \mathrm{C}$ and increased of the relative humidity from 47.4 to 64.1 and 
from 47.4 to $61.5 \%$ were 65.5 and $63.9 \mathrm{~kW}$ with 72.7 and $69.7 \%$ cooling efficiency, respectively.

\section{REFERENCES}

Ashrae. (1983). Evaporative Air-cooling Equipment. Chapter 4. Equipment Handbook. American Society of Heating, Refrigeration and Air-Conditioning Engineers. Atlanta, Georgia, USA.

Cobb, (2012). Broiler management guide. s.l.:s.n.

Heidarinejad G., M. Bozorgmehr, S. Delfani, and J. Esmaeelian. (2009). Experimental investigation of two-stage indirect/direct evaporative cooling system in various climatic conditions, Building and Environment. 44: 2073-2079.

Johann P. T. (2015). Design and performance evaluation of a HYDROSOL space heating and cooling system. Thesis presented in partial fulfilment of the requirements for the degree of Master of Engineering (Mechatronic) in the Faculty of Engineering at Stellenbosch University. Stellenbosch University https://scholar.sun.ac.za.

John P., (2006). Benefits of Upgrading from Two-Inch to Six-Inch vaporative Cooling Pads on Broiler Farms. Agricultural \& Natural Resource Engineering Applications. Department of Agricultural and Biological Engineering. ANREA - 061.

Lemouari M., M. Boumaza, and A. Kaabi. (2009). Experimental analysis of heat and mass transfer phenomena in a direct contact evaporative cooling tower. Energy Conversion and Management. 50(6):1610-1617.

Ralebhat Rahul, Kothmire Pramod and Sardeshpande Vishal (2016). Low cost cooling system for poultry shed. International Engineering Research Journal (IERJ) Special Issue., 1271-1275, June 2016, ISSN 2395-1621, www.ierjournal.org. 


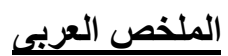

\section{تعظيم الإســـتفادة من وحدات تبريد تقليدية لعنابر دواجن التسمين}

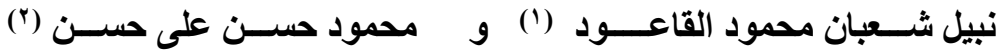

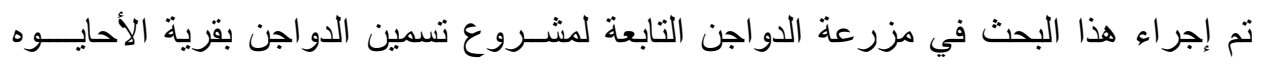

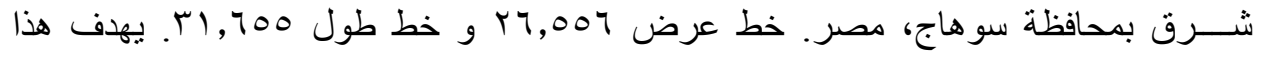
البحث إلى تعظيم الاستفادة من نظام التبريد الحالي لمزرعة الدواجن. وقد أجريت التجربة في في

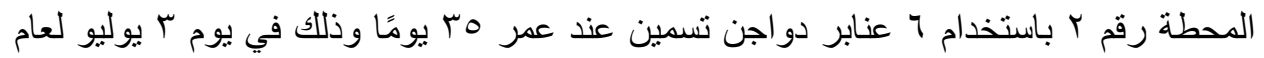

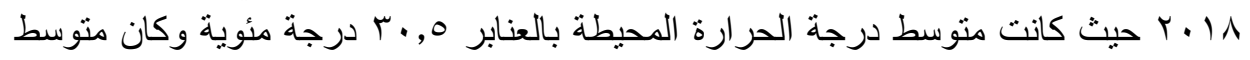

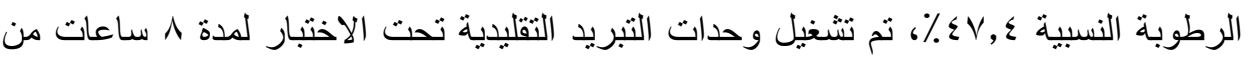

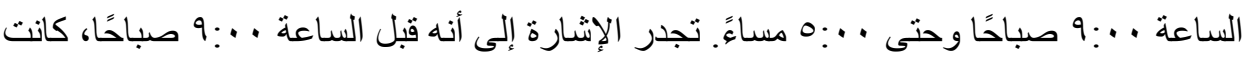

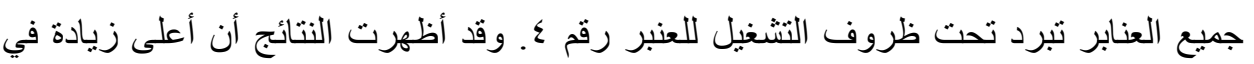
درجة الحرارة قد تحققت في ظل ظروف التشغيل للعنبر رقم ب (يتم تشغيل وحدات التبريد

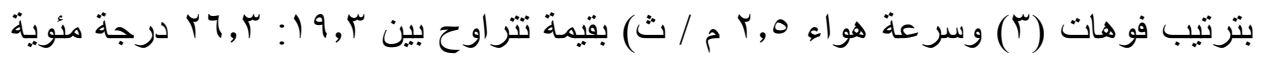

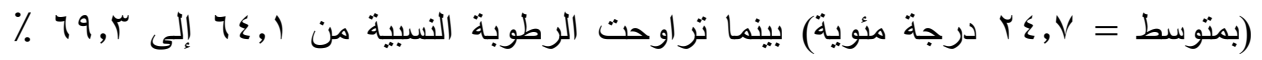

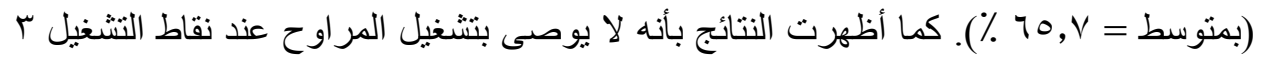

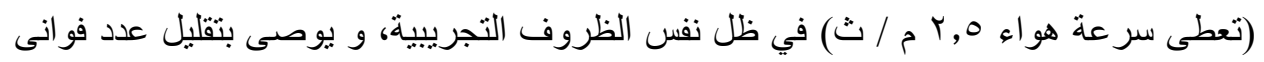

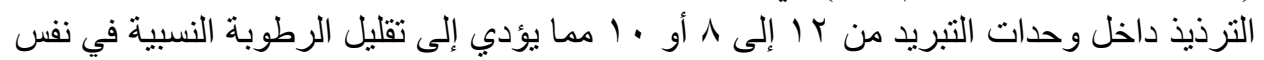

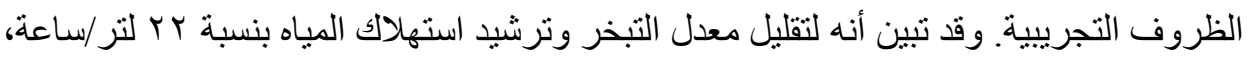
يتم استخدام وحدات التبريد تحت ظروف تشغيل العنابر ه أو 7 مقارنة بظروف تشفئ تشغيل العنبر رقم ع. كما تبين ايضا أنه تحت ظروف تشغيل العنابر رقم 0 و 7 كانت إجمالي قيمة طاقة التبريد

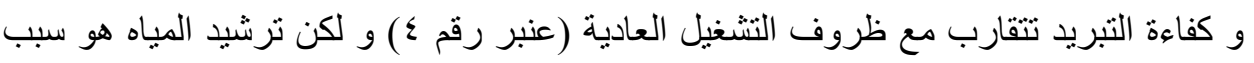

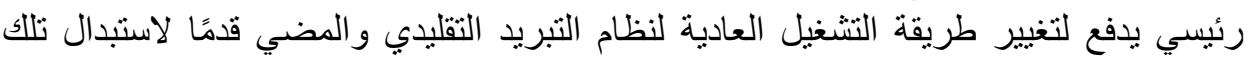
الأنظمة التقليدية بأخرى حديثة.

( ( ) و (Y ) مدرس الهندة الزراعية بكلية الهندسة الزراعية بجامعة الأزهر فرع اسيوط. 